\title{
Gastric fundic gland polyps: can histology be useful to predict proton pump inhibitors use?
}

\author{
Hugo Leite de Farias BRITO, Cynthia BARROS, Marcelle Vieira FREIRE, \\ Miraldo Nascimento da SILVA FILHO and Tereza Virgínia NASCIMENTO
}

\begin{abstract}
Background - Fundic gland polyps allegedly increased in frequency in recent decades, and had attracted great attention due to possible association with prolonged proton pump inhibitor therapy. Prolonged use of this drug could cause parietal cell hyperplasia, obstruction of glandular lumen and cystic dilation of the gland. Objective - This study aims to analyze clinical and pathological features of fundic gland polyps in patients with and without proton pump inhibitor therapy in a selected population from Brazil. Methods - It was selected a sample of 101 Brazilian patients ( 78 females and 23 males), from a five years retrospective search of the files from a private pathology laboratory. The patients had an average age of 57 years and we included patients with a histological diagnosis of fundic gland polyp. The clinical data were obtained from their files and all histological slides were reviewed and examined with hematoxylin and eosin (HE) and Giemsa. Results - Information about the use or non-use of proton pump inhibitors (PPI) was obtained in 84 patient files. In 17 cases we could not determine if PPI were used or not. Among those in which the information was available, a positive history of anti-acid therapy was observed in $63(75.0 \%)$ patients. Parietal cell hypertrophy/hyperplasia and parietal cell protrusions were detected in most slides. Histological findings were identical in PPI users and PPI negative patients. Helicobacter pylori infection was detected in just two samples. Epithelial dysplasia or adenocarcinoma were not observed in our cases. Histopathological analysis of fundic gland polyps could not distinguish between PPI and non-PPI related cases. Parietal cell cytoplasmic protrusions, an alleged marker of prolonged acid suppression therapy, was detected in both groups. Conclusion - Histological features could not discriminate anti-acid therapy related fundic glands polyps in our patients. HEADINGS - Gastric mucosa. Polyps, pathology. Proton pump inhibitors.
\end{abstract}

\section{INTRODUCTION}

Fundic gland polyps (FGP) are small exophytic and usually asymptomatic lesions of fundic and upper body gastric mucosa. At histology, dilated cystic glands lined with parietal cells, chief cells and occasionally with mucous foveolar cells characterize them. These polyps can occur in hereditary or non-hereditary context. Hereditary cases are mainly associated with the Familial Adenomatous Polyposis Syndrome (FAP) and frequently multiple lesions can be found, such as Fundic Gland Polyposis ${ }^{(1-2)}$.

Sporadic fundic gland polyps are reported as the most common type of gastric polyp ${ }^{(1)}$. It can be single or multiple and usually is an incidental finding in patients submitted to upper endoscopy or on chronic treatment with proton pump inhibitor (PPI) medication ${ }^{(3-8)}$. Prolonged use of this drug could cause parietal cell hyperplasia, obstruction of glandular lumen and cystic dilatation of the gland ${ }^{(5-8)}$. In fact, it seems that growing incidence of fundic gland polyps parallels increasing medical use of proton pump inhibitors ${ }^{(7,9-11)}$. A negative association with Helicobacter pylori (H. pylori) infection and prevalence among female patients has also been recorded ${ }^{(2-3,8)}$.

The aim of this study is to analyze clinical and pathological features of fundic gland polyps in patients with and without proton pump inhibitor therapy in a selected population from Brazil.

\section{METHODS}

This is an observational, retrospective and descriptive study based on morphological analyses and primary clinical data collection from patients with gastric fundic gland polyps. We performed a five years retrospective search of the pathology files from a private Anatomic Pathology Laboratory. All cases with a final diagnosis of FGP were selected. A total of 101 patients with a histological diagnosis of FGP were selected from an Anatomic Pathology Laboratory files.

Representative microscopic slides of these cases were retrieved from files and reviewed by a pathologist from this study. All biopsies were previously fixed in $40 \mathrm{~g} / \mathrm{L}$ formaldehyde and included in paraffin. Histological sections were stained with hematoxylin and eosin (HE) and Giemsa. Number and size of tissue fragments submitted to histopathological analysis were obtained from gross description in pathology reports. Histological features analyzed in all polyps consisted of: type of cyst epithelial lining (parietal cell, chief cell, mucous cell); parietal cell and superficial foveolar epithelium morphology (parietal cell hyperplasia, parietal cell protrusions, foveolar hyperplasia); presence or not of intraglandular secretion, glandular atrophy, intestinal metaplasia, epithelial dysplasia, chronic inflammatory infiltrate in lamina propria, neutrophilic infiltrate and $H$. pylori infection. Parietal cell protrusions were defined as tongue- 
like cytoplasmic protrusions into dilated glandular lumen. All microscopic sections in each slide were scrutinized for the parameters above. These features were reported as positive or negative. Parietal cell protrusions were also classified as focal (limited area in a polyp) or diffuse (detected in most polyp glands). Gastric mucosa from other sites were also studied whenever provided. H. pylori search was performed in HE and Giemsa stains at high power microscopy (40x). Histological analysis was blinded for patients' clinical and medication intake history. Clinical information were collected from medical files from each patient in a private Gastroenterology clinic.

Statystical analysis were performed with Prism Software for MacIntosh $4.0{ }^{\circledR}$, using the Chi-square test and the Student t test. The significance level was set at $P<0.05$.

The study was approved by the ethical committee of Federal University of Sergipe (UFS) and followed the precepts of the declaration of Helsinki and the resolution 466/2012 of the National Health Council.

\section{RESULTS}

From the 101 patients sample, $23(23 \%)$ were male and $78(77 \%)$ were female. Mean age was 57 years, which ranged from 21 to 98 years. History of PPI treatment was retrieved from the medical files of 84 patients (83\%). Clinical data are depicted in TABLE 1.

The number of fragments obtained by endoscopy and submitted to histological analysis ranged from one $(7.9 \%)$, between two and ten $(73.3 \%)$ and over ten $(18.8 \%)$. The majority of polyps $(79.2 \%)$ measured between 2 and $5 \mathrm{~mm}$. Histological analysis disclosed a mixed cell population, which consisted of parietal, chief and mucous cells lining the cysts in most polyps (78.2\%). These mixed type polyps showed some hybrid cysts lined by both mucous and oxyntic cells (FIGURE 1). A minority of polyps (21.8\%) consisted exclusively of cysts lined by parietal or chief cells (oxyntic type), mainly the former (FIGURE 2). Morphological description and comparison between groups was summarized in TABLE 2.

TABLE 1. Patients clinical characteristics.

\begin{tabular}{lcc}
\hline Number of patients & $\mathbf{N}$ & $\%$ \\
& 101 & 100 \\
\hline Gender & 23 & \\
Male & 78 & $23 \%$ \\
Female & & $77 \%$ \\
Age & 5 & \\
$0-30$ & 58 & $5 \%$ \\
$31-60$ & 38 & $57 \%$ \\
$>60$ & & $38 \%$ \\
PPI use & 17 & \\
Unknown & 19 & $17 \%$ \\
No use & 65 & $64 \%$ \\
Use & 16 & $16 \%$ \\
$<01$ year & 38 & $38 \%$ \\
$01-05$ years & 11 & $11 \%$ \\
$>05$ years & & \\
\hline
\end{tabular}

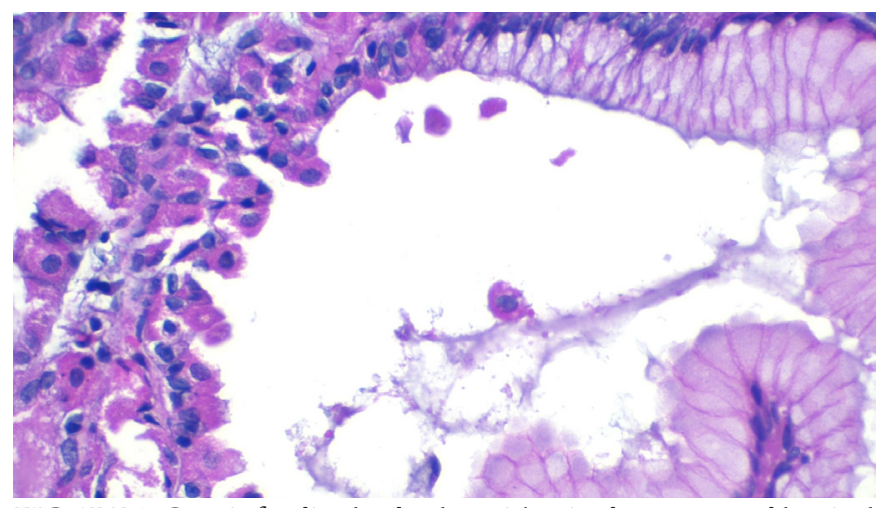

FIGURE 1. Gastric fundic gland polyp with mixed type cyst and luminal secretion.

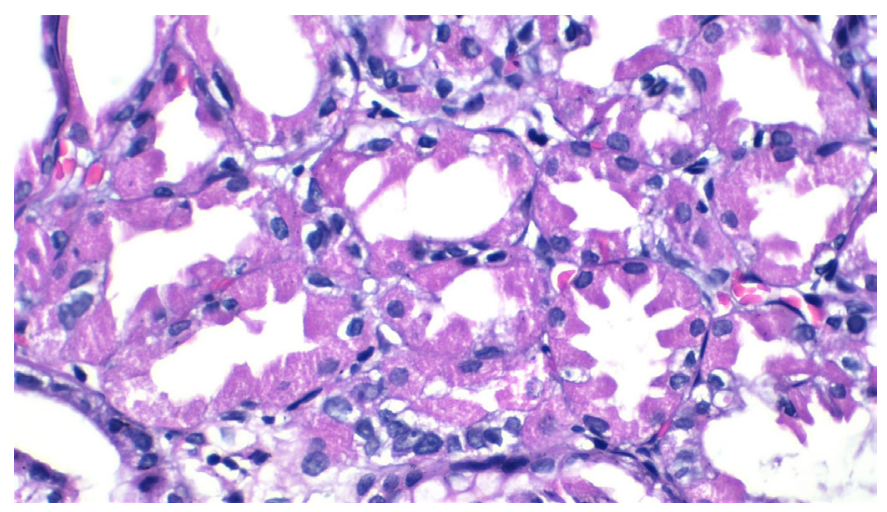

FIGURE 2. Oxyntic type cyst with apical cytoplasmic protrusions of parietal cells.

Mild antral gastritis was observed in 27 cases and limited areas of antral intestinal metaplasia were detected in only three cases. Dysplasia was not observed in fundic or antral mucosa in any case. Histological findings were identical in PPI users and PPI negative patients, with no statistically significant finding $(P>0.05)$.

\section{DISCUSSION}

Fundic gland polyps has attracted great attention due to possible association with PPI prolonged therapy and some alleged increase in frequency in recent decades ${ }^{(12)}$. Indeed, they are frequently reported as the most common gastric polyps in Western population $^{(1,13)}$. Nevertheless, in a study from Brazil, FGP is the second in frequency $(16 \%)$, much less than hyperplastic polyps $(71 \%)^{(14)}$. Similar results were described in a Spanish population based study ${ }^{(15)}$.

In our study, most polyps occurred in adult females with a positive history of PPI treatment. Female prevalence is a wellknown characteristic of $\mathrm{FGP}^{(2,8,11-12)}$. It could reflect a direct gender related influence in fundic gastric mucosa proliferation or a higher prevalence of PPI use among female patients.

Most lesions, in our study, measured more than $2.0 \mathrm{~mm}$ and were endoscopically removed as gastric polyps suspected to be a FGP. Actually, a diagnosis of FGP can be achieved by endoscopy with a high degree of accuracy because they detach completely at their base by forceps biopsy ${ }^{(16)}$.

A high frequency of PPI use was also found in our cases favoring a contributory role of acid suppression therapy in FGP 
TABLE 2. Histological characteristics and comparison between histological findings found in PPI user and PPI negative patients.

\begin{tabular}{|c|c|c|c|c|c|}
\hline \multirow[b]{2}{*}{ Pathological features } & \multicolumn{2}{|c|}{$A(n=84)$} & \multirow{2}{*}{$\begin{array}{c}\text { B ( } \mathrm{n}=17) \\
\text { PPI use } \\
\text { unknown }\end{array}$} & \multirow[b]{2}{*}{$\begin{array}{c}\text { Total } \\
\mathbf{N}=101(100 \%)\end{array}$} & \multirow[b]{2}{*}{$P$-value } \\
\hline & $\begin{array}{l}\text { PPI positive } \\
(n=63)\end{array}$ & $\begin{array}{l}\text { PPI negative } \\
\quad(\mathrm{N}=21)\end{array}$ & & & \\
\hline \multicolumn{6}{|l|}{ Cyst lining } \\
\hline Mixed & 49 & 17 & 13 & $79(78.2 \%)$ & \multirow[t]{2}{*}{$1.00 *$} \\
\hline Oxintic & 14 & 4 & 4 & $22(21.8 \%)$ & \\
\hline \multicolumn{6}{|l|}{ Parietal cell hyperplasia } \\
\hline Negative & 2 & 0 & 1 & $3(3 \%)$ & $1.00 *$ \\
\hline \multicolumn{6}{|l|}{ Parietal cell protrusions } \\
\hline Positive focal & 19 & 8 & 11 & $38(37.6 \%)$ & \multirow{2}{*}{$0.3051 *$} \\
\hline Positive diffuse & 28 & 11 & 3 & $42(41.6 \%)$ & \\
\hline Negative & 35 & 10 & 6 & $51(50.5 \%)$ & $0.6165 * *$ \\
\hline \multicolumn{6}{|l|}{ Foveolar hyperplasia } \\
\hline Positive & 18 & 6 & 3 & $27(26.7 \%)$ & \multirow[t]{2}{*}{$1.00 *$} \\
\hline Negative & 45 & 15 & 14 & $74(73.3 \%)$ & \\
\hline \multicolumn{6}{|l|}{ H. pylori infection } \\
\hline Positive & 1 & 1 & 0 & $2(2 \%)$ & \multirow[t]{2}{*}{$0.4398 *$} \\
\hline Negative & 62 & 20 & 17 & $99(98 \%)$ & \\
\hline
\end{tabular}

A: clinical information regarding PPI use available; B: clinical information regarding PPI use not available. PPI: proton pump inhibitor. *Fisher's exact test. ** Chi-square test.

development in gastric mucosa, which is in accordance with many reports in literature. Actually, FGP genesis seems to be related to prolonged PPI use $\mathrm{s}^{(4,6-8,11)}$.

Cats et al. ${ }^{(5)}$, showed parietal cell proliferation, development of cytoplasmic protrusions and glandular cystic dilatation in patients on chronic PPI therapy. Histological changes in oxyntic mucosa were observed in $18 \%$ of early treatment patients and in $86 \%$ of patients over one year of treatment. Similar results were obtained by Jalving et al. ${ }^{(8)}$ who also describes the development of FGP in $18 \%$ of the group with less than one-year-treatment-patients and in $57 \%$ of the patients after one year of therapy. However, the notion of PPI therapy as a risk factor for FGP development is declined by some researchers ${ }^{(17,18)}$.

PPI treatment in mices can induce morphological changes in epithelial gastric cells, with enlargement of parietal cells and decreased number of chief cells ${ }^{(19)}$. Hypergastrinemia, secondary to PPI chronic use can lead to parietal cell proliferation and hyperplasia ${ }^{(5,8-9)}$. Prolonged acid suppression therapy also induces obstruction of parietal cells canaliculi with hydrochloric acid, cytoplasmic hypertrophy and apical cell protrusions. Increased intraglandular pressure results in cystic dilatation ${ }^{(5,19-20)}$. FGP can results from a dual mechanism of cellular proliferation and obstruction of glandular secretion flow, both related to PPI therapy ${ }^{(20)}$.

Parietal cell hyperplasia and parietal cell protrusions were detected in most cases of FGP in this study in patients with and without PPI therapy. Parietal cell protrusions were only focally observed in many polyps and could be undetected without careful histologic analysis.
Cysts were lined by a mixed cell population in $77 \%$ of cases, which includes parietal, chief and mucous foveolar-type cells. These findings are the classical histological picture of FGP, with disorganized glands, which substantiated the classification of these lesions as hamartomatous in the past $\mathrm{t}^{(1,21)}$. Mucous lined cysts probably is a consequence of secretion flow obstruction and pits dilatation, since foveolar hyperplasia was only observed in $27 \%$ of cases. In fact, true proliferative changes of foveolar epithelium are more related to chronic active gastritis and $H$. pylori infection. The presence of intraglandular mucous plugs and exfoliated cells in almost half $(47.5 \%)$ of our sample reinforces the glandular flow obstruction hypothesis for FGP development.

A minority of polyps (22\%) consisted of cysts lined by parietal/ chief cells only. Some of these cases showed tiny cysts in a background of hyperplastic and hypertrophied oxyntic mucosa with parietal cell protrusions, a histological change frequently described in non-polypoid gastric mucosa of chronic PPI users ${ }^{(3,5,8)}$. Nevertheless, we could not find a specific morphologic marker of PPI related-FGP in our study, since these findings were also detected in patients without use of PPI drugs. Recently, these morphologic changes in oxyntic mucosa have also been linked to $H$. pylori chronic gastritis $^{(22)}$. Indeed, the precise role of anti-acid therapy in oxyntic cell changes is still a debatable issue by some authors ${ }^{(23)}$

A very low frequency of $H$. pylori infection $(2 \%)$ was detected in our study which corroborates the well-known inverse association of FGP and this bacteria ${ }^{(2,3,8)}$. Genta et al. describes a $0.5 \%$ frequency of $H$. pylori infection in 6081 patients with $\mathrm{FGP}^{(24)}$. Cats et al. ${ }^{(5)}$ speculates that the degradation of gastric mucus by 
H. pylori proteases acts as a protection factor for cystic dilatation by improving glandular secretion. In fact, acquisition of $H$. pylori infection can cause regression of $\mathrm{FGP}^{(25)}$.

Mutations in $\beta$-catenin have been described in many cases of sporadic $\mathrm{FGP}^{(13,26-27)}$. Mutations in APC/ $\beta$-catenin genes could induces parietal cell proliferation and deregulate cell membrane function, leading to glandular obstruction and cystification ${ }^{(20)}$. According to Abraham ${ }^{(28)}$, they are neoplastic growths that have very limited potential for malignant transformation. Actually, low grade dysplasia is detected in only $1 \%$ of sporadic FGPs ${ }^{(28-30)}$.

Dysplasia or gastric adenocarcinoma were not identified in any case in 101 fundic gland polyps examined in the present study. Our findings supports the established concept of a benign proliferative lesion, no matter it discloses some neoplastic-like features at molecular level.

\section{CONCLUSION}

Fundic gland polyps were more prevalent in middle-aged women, frequently with a positive history of proton pump inhibitors therapy and a very low frequency of $H$. pylori infection. Parietal cell protrusions were equally detected in PPI and non-PPI related polyps. Histological features could not discriminate anti-acid therapy related fundic glands polyps in our patients.

\section{ACKNOWLEDGEMENTS}

The authors thank Sonia Lima, MD and Roque Pacheco MD, $\mathrm{PhD}$ for logistics and technical assistance.

\section{Authors' contribution}

Brito HLF: conception and design, analysis and interpretation, writing the article, critical revision of the article, data collection, provision of materials, patients and resources, statistical expertise, literature search, logistic support, analysis of the slides. Barros C: analysis and interpretation, writing the article, data collection, literature search. Freire MV: analysis and interpretation, writing the article, statistical expertise, literature search. Silva Filho MN: analysis and interpretation, provision of materials, patients and resources, logistic support. Nascimento TV: analysis and interpretation, critical revision of the article, provision of materials, patients and resources, logistic support.

Brito HLF, Barros C, Freire MV, Silva Filho MN, Nascimento TV. Pólipos de glândulas fúndicas: a histologia pode ser utilizada para prever uso de inibidores de bomba de próton? Arq Gastroenterol. 2018;55(4):380-4.

RESUMO - Contexto - Os pólipos das glândulas fúndicas do estômago supostamente aumentaram em frequência nas últimas décadas e atraíram grande atenção devido à possível associação com a terapia prolongada com inibidores da bomba de prótons. O uso prolongado deste fármaco pode causar hiperplasia das células parietais, obstrução do lúmen glandular e dilatação cística da glândula. Objetivo - Este estudo tem como objetivo analisar os aspectos clínicos e patológicos dos pólipos das glândulas fúndicas em pacientes com e sem terapia com inibidores da bomba de prótons em uma população selecionada do Brasil. Métodos - Foi selecionada uma amostra de 101 pacientes brasileiros ( 78 do sexo feminino e 23 do sexo masculino), a partir de uma pesquisa retrospectiva de cinco anos dos arquivos de um laboratório privado de patologia. Os pacientes tinham uma idade média de 57 anos e foram incluídos pacientes com diagnóstico histológico de pólipo das glândulas fúndicas. Os dados clínicos foram obtidos a partir de seus prontuários e todas as lâminas histológicas foram revisadas e examinadas com hematoxilina e eosina (HE) e Giemsa. Resultados - Informações sobre o uso ou não uso de inibidores da bomba de próton (IBP) foram obtidas em 84 prontuários de pacientes. Em 17 casos, não foi possível determinar se o IBP foi usado ou não. Entre aqueles em que a informação estava disponível, observou-se uma história positiva de terapia com IBP em 63 (75,0\%) pacientes. A hipertrofia das células parietais/hiperplasia e protrusões das células parietais foram detectadas na maioria das lâminas. Os achados histológicos foram idênticos em usuários de IBP e pacientes não usuários. A infecção por Helicobacter pylori foi detectada em apenas duas amostras. A displasia epitelial ou o adenocarcinoma não foram observados em nossos casos. A análise histopatológica dos pólipos das glândulas fúndicas não pôde distinguir entre os casos IBP e não relacionados ao IBP. As protuberâncias citoplasmáticas das células parietais, um suposto marcador de terapia prolongada de supressão de ácido, foram detectadas em ambos os grupos. Conclusão-Características histológicas não podem discriminar os pólipos das glândulas fúndicas relacionados à terapia anti-secretora em nossos pacientes.

DESCRITORES - Mucosa gástrica. Pólipos, patologia. Inibidores da bomba de prótons.

\section{REFERENCES}

1. Lauwers GY, Carneiro F, Graham DY, Curado MP, Franceschi S, Montgomery E, et al. Gastric carcinoma. In: Haboubi N. Pathology and genetics: Tumours of the digestive system. Surg Oncol. 2000;9:144-5.

2. Burt RA. Gastric fundic gland polyps. Gastroenterology. 2003;125:1462-9.

3. Graham DY, Genta RM. Long-term proton pump inhibitor use and gastrointestinal cancer. Curr Gastroenterol Rep. 2008;10:543-7.

4. Choudhry U, Boyce HW, Coppola D. Proton Pump Inhibitor-Associated Gastric Polyps: A Retrospective Analysis of Their Frequency, and Endoscopic, Histologic, and Ultrastructural Characteristics. Am J Clin Pathol. 1998;110:615-21.

5. Cats A, Edschenk B, Bloemena E, Roosendaal R, Lindeman J, Biemond I, et al. Parietal cell protrusions and fundic gland cysts during omeprazole maintenance treatment. Hum Pathol. 2000;31:684-90.

6. El-Zimaith HM, Jackson FW, Graham DY. Fundic gland polyposis developing during omeprazole therapy. Am J Gastroenterol. 1997;92:1858-60.
7. Freeman HJ. Proton pump inhibitors and an emerging epidemic of gastric fundic gland polyposis. World J Gastroenterol. 2008;14:1318.

8. Jalving M, Koornstra JJ, Wesseling J, Boezen HM, Jong SD, Kleibeuker JH. Increased risk of fundic gland polyps during long-term proton pump inhibitor therapy. Aliment Pharmacol Ther. 2006;24:1341-8.

9. Kuipers EJ. Proton pump inhibitors and gastric neoplasia. Gut. 2006;55:1217-21.

10. Samarasam I, Roberts-Thomson J, Brockwell D. Gastric fundic gland polyps: a clinico-pathological study from North West Tasmania. ANZ J Surg. 2009;79: 467-70.

11. Zelter A, Fernandez JL, Bilder C, Rodriguez P, Wonaga A, Dorado F, et al. S1082 Fundic Gland Polyps and Association with Proton Pump Inhibitor Intake: A Prospective Study in 1,780 Upper Gastroduodenal Endoscopies. Gastroenterology. 2009;136(5) 
12. Cao H, Wang B, Zhang Z, Zhang H, Qu R. Distribution trends of gastric polyps: An endoscopy database analysis of 24121 northern Chinese patients. J Gastroenterol Hepatol. 2012;27:1175-80.

13. Sekine S, Shibata T, Yamauchi Y, Nakanishi Y, Shimoda T, Sakamoto M, et al. $\beta$-Catenin mutations in sporadic fundic gland polyps. Virchows Archiv. 2001;440:381-6

14. Morais DJ, Yamanaka A, Zeitune JMR, Andreollo NA. Gastric polyps: a retrospective analysis of 26,000 digestive endoscopies. Arq Gastroenterol. 2007;44:14-7

15. García-Alonso FJ, Martín-Mateos RM, González-Martín JÁ, Foruny JR, Vázquez-Sequeiros E, Miquel DBD. Gastric polyps: analysis of endoscopic and histological features in our center. Rev. Esp. Enferm. Dig. 2011;103:416-20.

16. Weston BR, Helper DJ, Rex DK. Positive predictive value of endoscopic features deemed typical of gastric fundic gland polyps. J Clin Gastroenterol. 2003;36: 399-402.

17. Declich P, Tavani E, Bellone S, Porcellati M, Pastori L, Omazzi B, et al. Sporadic fundic gland polyps: what happened before? Gut. 2004;53:1721

18. Vieth M, Stolte M. Fundic Gland Polyps Are Not Induced by Proton Pump Inhibitor Therapy. Am J Clin Pathol. 2001;116:716-20.

19. Masaoka T, Suzuki H, Hibi T. Pleotropic Effects of Proton Pump Inhibitors Guest Editor: Yuji Naito Gastric Epithelial Cell Modality and Proton Pump Inhibitor. J Clin Biochem Nutr. 2008;42:191-6.

20. Rubio CA. Plugs clog the glandular outlets in fundic gland polyps. Int J Clin Exp Pathol. 2010;3:69-74.

21. Odze R, Marcial M, Antonioli D. Gastric fundic gland polyps: A morphological study including mucin histochemistry, stereometry, and MIB-1 immunohistochemistry. Hum Pathol. 1996;27:896-903.
22. Kumar KR, Iqbal R, Coss E, Park C, Cryer B, Genta RM. Helicobacter gastritis induces changes in the oxyntic mucosa indistinguishable from the effects of proton pump inhibitors. Hum Pathol. 2013;44:2706-10.

23. Declich P, Belloni J, Tavani E, Omazzi B, Bortoli A, Devani M, et al. Fundic gland polyps and proton pump inhibitors: an obvious link, or an open question? Hum Pathol. 2014;45:1122-3.

24. Genta RM, Schuler CM, Robiou CI, Lash RH. No Association Between Gastric Fundic Gland Polyps and Gastrointestinal Neoplasia in a Study of Over 100,000 Patients. Clin Gastroenterol Hepatol. 2009;7:849-54.

25. Watanabe N. Regression of fundic gland polyps following acquisition of Helicobacter pylori. Gut. 2002;51:742-5.

26. Torbenson M, Lee J-H, Cruz-Correa M, Ravich W, Rastgar K, Abraham SC, et al. Sporadic Fundic Gland Polyposis: A Clinical, Histological, and Molecular Analysis. Mod Pathol. 2002;15:718-23.

27. Abraham SC, Park SJ, Mugartegui L, Hamilton SR, Wu T-T. Sporadic Fundic Gland Polyps with Epithelial Dysplasia. Am J Pathol. 2002;161:1735-42.

28. Abraham SC. Fundic Gland Polyps: Common and Occasionally Problematic Lesions. Gastroenterol Hepatol (N Y). 2010;6:48-51.

29. Wu T-T, Kornacki S, Rashid A, Yardley JH, Hamilton SR. Dysplasia and Dysregulation of Proliferation in Foveolar and Surface Epithelia of Fundic Gland Polyps From Patients With Familial Adenomatous Polyposis. Am J Surg Pathol. 1998;22:293-8.

30. Sebastian S, Qasim A, Mcloughlin R, O'Morain CA, O'Connor HJ. Fundic gland polyps: not so trivial entity and worth evaluation. Gastroenterology. 2004;126:1497-8. 